\title{
Eksplorasi Konsep Diri para Pengguna TikTok dalam Memenuhi Social Needs pada Uses and Gratification Theory
}

\author{
Filza Alifah Hasny ${ }^{1 *}$, Shavira Hanza Renadia ${ }^{2}$ Irwansyah $^{3}$ \\ ${ }^{1,2,3}$ Fakultas Ilmu Sosial dan Ilmu Politik, Universitas Indonesia \\ J1. Margonda Raya, Pondok Cina, Kecamatan Beji, Kota Depok, Jawa Barat \\ E-mail: ${ }^{1}$ filza.alifah@ui.ac.id, ${ }^{2}$ filza.alifah@ui.ac.id, ${ }^{3}$ irwansyah09@ui.ac.id
}

Received: June 2021; Accepted: October 2021; Published: December 2021

\begin{abstract}
This qualitative study focuses on self-exploration of TikTok users in finding and creating educational content with fellow social network users. Researchers see the role of human needs psychologically and socially, which raises certain expectations from using TikTok and leads to fulfillment of needs. Researchers also saw the comparison of Gratification Sought (GS) with Gratification Obtained (GO) as the fulfillment of the needs sought to achieve the satisfaction desired by individuals in using TikTok. Researchers found that there were internal and external factors in self-exploration that influenced the fulfillment of the needs of using TikTok.
\end{abstract}

Keywords: TikTok; Uses and Gratification; social media; self-concept; expectation; satisfaction.

\begin{abstract}
Abstrak
Studi kualitatif ini berfokus pada ekplorasi diri para pengguna TikTok dalam mencari dan membuat konten edukatif dengan sesame pengguna jejaring sosial. Peniliti melihat adanya peran kebutuhan manusia secara psikologis dan sosial, yang menimbulkan harapan terentu dari penggunaan TikTok dan menimbulkan pemenuhan kebutuhan. Peneliti juga melihat perbandingan Gratification Sought (GS) sebagai pemenuhan kebutuhan yang dicari untuk mencapai suatu kepuasaan dengan Gratification Obtained (GO) sebagai pemenuhan kebutuhan yang dicari untuk mencapai suatu kepuasaan yang diinginkan oleh individu dalam penggunaan TikTok. Ditemukan adanya faktor internal dan eksternal dalam eksplorasi yang mempengaruhi pemenuhan kebutuhan penggunaan TikTok.
\end{abstract}

Kata kunci: TikTok; Uses and Gratification; media sosial; konsep diri; harapan; pemuasan.

\section{PENDAHULUAN}

Teori uses and gratification digunakan peneliti dalam penulisan ini. Teori ini diperkenalkan oleh Herbert Blumer dan Elihu Katz pertama kali pada tahun 1974 dalam karya nya yang tema "The Uses of Mass Communications: Current Perspectives on Gratification Research". Teori kegunaan dan kepuasan ini menekankan bahwasanya seseorang dapat secara selektif menseleksi dan mengkonsumsi media sesuai kebutuhan masing-masing individu. Pengguna media adalah sosok yang aktif pada suatu proses komunikasi hal itu ditunjukan dengan cara bagaimana mereka berusaha untuk mendapatkan sumber informasi dari media yang paling sesuai dalam memenuhi kebutuhan nya.

Fenomena penggunan jejaring sosial media TikTok berawal muncul pada tahun 2012 yang didirikan oleh ByteDance. Salah satu aplikasi media sosial berbasis audio visual yang banyak diminati saat ini adalah TikTok. Aplikasi TikTok banyak diminati oleh remaja karena menghibur, juga membantu meningkatkan kreativitas dalam mengedit dan membuat sebuah konten video yang menarik perhatian publik, tetapi tak jarang juga aplikasi ini membuat para remaja menjadi lupa akan waktu dan tempat dalam menggunakannya. Aplikasi ini pun membuat penggunanya menjadi berlomba-lomba untuk viral, bahkan demi mendapatkan respon dan likes yang banyak, mereka rela melakukan hal apa saja. Aplikasi TikTok tidak hanya menarik perhatian anak remaja melainkan orang dewasa. Saat ini pengguna TikTok juga berasal dari

doi: https://doi.org/10.51544/jlmk.v5i2.1671

(C) 2021 Jurnal Lensa Mutiara Komunikasi. This is an open access article under the CC BY-SA license Website: http://e-journal.sari-mutiara.ac.id/index.php/JLMI

http://e-journal.sari-mutiara.ac.id 
selebriti local dan mancanegara bahkan pejabat dan beberapa perusahaan juga menggunakan aplikasi audio visual ini. Hal ini yang kemudian membuat peneliti tertarik untuk meneliti "Penggunaan Aplikasi Media Sosial Berbasis Audio Visual Dalam Membentuk Konsep Diri".

Rumusan masalah pada kajian ini adalah bagaimana penggunaan aplikasi media sosial yang berbasis audio-visual dalam eksplorasi konsep diri pada konten edukatif dan informatif. Kajian ini bermaksud untuk memahami penggunaan aplikasi media sosial berbasis audio visual dalam membentuk konsep diri penggunanya.

\section{TINJAUAN LITERATUR}

Teori Uses and Gratification banyak dibahas dan dipelajari dalam topik Sosial Media. Sosial Media sendiri memiliki berbagai fungsi untuk memenuhi berbagai kebutuhan pengguna nya. Dalam sosial media akan kita temui banyak aplikasi yang di mediasi oleh komputer seperti blog, microblog, e-mail, platform video, dan juga pesan singkat. Para pengguna bisa secara aktif memilih media sesuai dengan kebutuhan dan preferensi masing-masing.

Pada penelitian sebelumnya yang ditulis oleh Dwi Putri Robiatul Adawiyah dalam judul "Pengaruh Penggunaan Aplikasi TikTok Terhadap Kepercayaan Diri Remaja di Kabupaten Sampang" memaparkan tentang pemakaian jejaring sosial TikTok yang dapat berdampak pada rasa percaya diri seseorang. Hasil nya ditemukan bahwa penggunaan Aplikasi TikTok dapat meningkatkan kepercayaan diri remaja Kabupaten Sampang sampai sebesar 54,5\%. Peningkatan kepercayaan diri diperoleh melalui muatan video dan tantangan positif dalam aplikasi TikTok. Namun, sikap bijak dan pengawasan berkala dari berbagai pihak tetap diperlukan agar para remaja tidak terjerumus kepada konten-konten negatif yang ada di dalam aplikasi.

Hal yang sama dikemukakan pada jurnal "Penggunaan Aplikasi Media Sosial Berbasis Audio Visual dalam Membentuk Konsep Diri (Studi Kasus Aplikasi Tiktok)” oleh Dian Novita Sari Chandra Kusuma, Roswita Oktavianti yang menjelaskan pemakaian jejaring sosial berbasis audio visual, TikTok diminati oleh semua jenjang usia. Usia mempengaruhi durasi pemakaian dari aplikasi TikTok, semakin kecil usia semakin terbatas durasi dalam menggunakan aplikasi TikTok dan sebaliknya. Hal ini dikarenakan masih adanya pengawasan dari orang tua maupun tugas sekolah yang membatasi mereka dalam menggunakan aplikasi TikTok. Aplikasi TikTok memberikan kepuasan sosial dan hiburan terhadap penggunanya dengan fitur yang mudah digunakan. Pada juenal ini narasumber dengan jenjang usia muda mereka menggunakan aplikasi TikTok untuk mengikuti perkembangan sosial, sedangkan narasumber dengan jenjang usia yang lebih dewasa mereka menggunakan aplikasi TikTok untuk mengisi waktu luang. Dalam pemanfaatannya, aplikasi TikTok dapat mempengaruhi pembentukan konsep diri dari penggunanya. Dari komentar positif narasumber mendapatkan kepercayaan diri dan dari komentar negatif narasumber membentuk mental yang kuat dalam menanggapi komentar tersebut sebagai pembelajaran. Aplikasi ini membentuk konsep diri pengguna ke arah yang baik seperti memberikan kreatifitas dan wawasan kepada penggunannya dalam mengedit, membuat konten, mendapat ilmu menari dan memasak. Aplikasi ini juga membentuk konsep diri penggunanya ke arah yang buruk, seperti kurangnya dalam mengatur waktu.

Dengan temuan yang ada pada kedua jurnal diatas maka penulis ingin mengetahui pemanfaatan positif pada media TikTok yang digunakan para remaja. Jika jurnal terdahulu membahas topik mengenai konsep diri yang dikemukanan pada jejaring sosial, maka penelitian ini akan membahas mengenai gratifikasi yang didapatkan setelah mencari atau memuat konten edukasi serta informative pada TikTok. 
Pilihan Individu dalam menggunakan sebuah media massa pasti dilandaskan pada suatu tujuan tertentu, dan hal ini dibahas dalam Teori uses and gratification. Media berusaha untuk memenuhi motif individu dalam menggunakan media massa, kebutuhan individu akan terpenuhi apabila motif dari individu telah terpenuhi. Sehingga media yang efektif merupakan media yang mampu memenuhi kebutuhan individu (Kriyantono, 2014:208).

Kepuasan yang dicari oleh tiap individu akan berbeda-beda sesuai dengan konsep diri yang dibentuk. William D Brooks memaparkan bahwasanya konsep diri merupakan pengetahuan dan penilaian mengenai diri kita. Pandangan tentang diri ini dapat bersifat fisik, sosial dan psikologis. (Widiarti, 2017:137).

Manfaat dan Tujuan menjadi alasan utama para pengguna untuk aktif memilih dan menggunakan suatu media massa. Perbedaan kebutuhan setiap individu menjadikan variatif nya pemilihan media massa di kalangan para pengguna. Teori Uses and Gratification ini mendalami bagaimana kapasitas media dalam kemampuan nya memuaskan kebutuhan audiens. Swalon dalam Jalaluddin Rakhmat yang dikutip oleh Romli memaparkan bahwa teori uses and gratification kerap kali digambarkan dalam a dramatic break with effect tradition of the past, hal ini merupakan inovasi dari model jarum hipodermik. Pada teori ini fokusnya adalah tentang bagaimana seseorang memperlakukan media, bukan sebaliknya. Dalam pemenuhan kebutuhan, audiens secara aktif berperan besar dalam memilih media nya. Dalam teori kegunaan dan kepuasan, ada beberapa hal yang secara tidak langsung mengartikan adanya tujuan tersendiri dalam berperilaku pada media. Disaat kebutuhan psikologis dari sebuah media massa telah tercukupo, maka apa yang menjadi tujuan dari pemakaian media telah terpenuhi (Romli, 2016).

Menurut Dariyo (2011:202), konsep diri memiliki dua aspek, pertama yaitu aspek fisiologis, aspek ini mencakup bentuk fisik, berat badan seseorang, warna kulit, wajah (rupawan, cantik, jelek), memiliki jasmani yang normal, sehat, atau memiliki kelemahan. Fisik seseorang dapat memberikan dampak seseorang dalam menilai diri sendiri, dan juga biasanya sesorang mengevaluasi orang lain dengan menilai terhadap fisik terlebih dahulu. Aspek psikologis memiliki lingkup analisa dalam tiga hal yaitu, kognisi (pengetahuan, hobi dan bakat, ide kreatif, teliti), afeksi (daya tahan, rajin, dan pekerja keras, kompetitif, tingkat kontrol diri), konasi (kecepatan dan ketelitian kerja, coping stres, resiliensi). Alasan narasumber menggunakan aplikasi TikTok inipun karena dorongan sosial yang berasal dari teman. Dalam pemanfaatan aplikasi TikTok narasumber banyak menggunakan aplikasi ini sebagai media komunikasi untuk mencari teman baru ataupun mempererat hubungan dengan teman dekat. Hal ini sejalan dengan penelitian terdahulu Azeharie (2014), yang meneliti Analisis Penggunaan Twitter Sebagai Media Komunikasi Selebritis di Jakarta. Azeharie mengatakan bahwa media sosial Twitter merupakan media yang sangat efektif untuk selebriti berkomunikasi dengan penggemarnya, yang berarti media sosial saat ini dimanfaatkan sebagai media komunikasi yang efektif terhadap individu lainnya.

Teori penggunaan dan gratifikasi adalah teori yang memaparkan bahwa individu menggunakan sebuah media massa dengan tujuan tertentu. media berusaha untuk memenuhi motif individu dalam menggunakan media massa, kebutuhan individu akan terpenuhi apabila motif dari individu telah terpenuhi. Sehingga media yang efektif merupakan media yang mampu memenuhi kebutuhan individu (Kriyantono, 2014:208). Gratification Sought (GS) merupakan pemenuhan kebutuhan yang dicari untuk mencapai suatu kepuasaan yang diinginkan oleh individu pada saat akan menggunakan media massa tertentu. Gratification Sought merupakan motif seseorang yang mendorong dalam menggunakan suatu media (Kriyantono, 2014:210-211). 
Kekuatan sosial media dalam memenuhi berbagai kebutuhan pengguna adalah unit analisa yang akan kami telaah. Analisis pada penulisan ini akan lebih fokus pada gratifikasi yang diharapkan dan Gratifikasi yang didapatkan baik dalam sisi motivasi sosial ataupun informasi dari keduanya. Bentuk-bentuk kepuasan yang diperoleh dari penggunaan TikTok ini juga akan kami bahas dalam penelitian ini. Perbandingan antara ekspektasi (Gratification Sought) dan hasil (Gratification Obtained) serta aplikasinya pada teori Uses and Gratification mungkin sudah banyak diteliti terutama pada studi kepuasan konsumer. Kenyataan nya gratifikasi yang di harapkan (Gratification Sought) tidak selalu didapatkan (Gratification Obtained) dalam kenyataan nya.

Tabel 1

Kajian Pustaka

\begin{tabular}{|c|c|c|c|}
\hline Judul dan Peneliti & Obyek & Metode & Hasil \\
\hline $\begin{array}{l}\text { "Pengaruh } \\
\text { Penggunaan Aplikasi } \\
\text { TikTok Terhadap } \\
\text { Kepercayaan Diri } \\
\text { Remaja di Kabupaten } \\
\text { Sampang" oleh Dwi } \\
\text { Putri Robiatul } \\
\text { Adawiyah (2020) }\end{array}$ & $\begin{array}{l}\text { Remaja di } \\
\text { Kabupaten } \\
\text { Sampang. }\end{array}$ & $\begin{array}{l}\text { Menggunakan } \\
\text { metode } \\
\text { penelitian } \\
\text { kuantitatif untuk } \\
\text { mengetahui } \\
\text { seberapa besar } \\
\text { pengaruh } \\
\text { penggunaan } \\
\text { aplikasi Tiktok } \\
\text { terhadap } \\
\text { kepercayaan diri } \\
\text { remaja di } \\
\text { Kabupaten } \\
\text { Sampang dari } \\
\text { sudut pandang } \\
\text { teori uses and } \\
\text { gratification. }\end{array}$ & $\begin{array}{l}\text { Dari hasil data persamaan regresi diperoleh nilai } \\
\text { koefisien regresi bernilai positif }(+) \text {, maka dapat } \\
\text { dikatakan bahwa penggunaan media sosial TikTok } \\
\text { berpengaruh positif terhadap kepercayaan diri } \\
\text { remaja. }\end{array}$ \\
\hline & & $\begin{array}{l}\text { Skala yang } \\
\text { digunakan } \\
\text { menggunakan } \\
\text { model Likert. }\end{array}$ & \\
\hline
\end{tabular}

"Penggunaan

Aplikasi Media

Sosial Berbasis

Audio Visual dalam

Membentuk Konsep

Diri (Studi Kasus

Aplikasi Tiktok)"

oleh Dian Novita

Sari Chandra

Kusuma, Roswita

Oktavianti (2020)

"Penggunaan dan

Pemenuhan

Kepuasan yang

Dicari oleh Pengguna

TikTok Pra-remaja

dan Remaja" oleh

Bucknell Bossen,

Christina and
Narasumber jenjang usia muda dan lebih dewasa.

Kelompok Pra-

Remaja dan

Remaja

pengguna

TikTok

\section{Menggunakan} metode penelitian kualitatif berupa wawancara mendalam.
Dalam pemanfaatannya, aplikasi TikTok dapat mempengaruhi pembentukan konsep diri dari penggunanya melalui komentar yang didapatkan. Usia mempengaruhi durasi pemakaian dari aplikasi TikTok, semakin kecil usia semakin terbatas durasi dalam menggunakan aplikasi TikTok dan sebaliknya.
Menggunakan metode penelitian kuantitatif dengan metode sampling pembagian kuesioner kepada 60 murid, analisis varian, analisis
Ditemukan adanya perilaku konsumtif di antara kelompok pra-remaja dan remaja. Pengaruh efek hiburan dalam aplikasi ini merupakan pendorong utama di balik perilaku konsumtif pasif, partisipatif dan kontributif. Kelompok pra-remaja lebih aktif dan lebih banyak menggunakan aplikasi Tiktok dibandingkan kelompok remaja. Berdasarkan teori psikologi remaja, Peneliti 
Kottasz, Rita (2020)

"Inilah Saatnya

TikTok :

Mengeksplor

Motivasi Generasi-Z

yang Ikut

Berpartisipasi pada

\#Tantangan" oleh

Johannes Ahlse,

Felix Nilsson, Nina

Sandström (2020) klaster, dan Log Likehood Method

$\begin{array}{cl}\text { Pengguna } & \text { Menggunakan } \\ \text { TikTok pada } & \text { metode penelitian } \\ \text { Generasi-Z } & \text { kualitatif dengan } \\ & \text { pendekatan teori } \\ & \text { dasar (Grounded } \\ & \text { Theory) }\end{array}$

Mahasiswa dan

Komunitas UCSD
Menggunakan metode penelitian kualitatif dengan metode snowball sampling dan wawancara mendalam. menemukan bahwa perilaku tersebut dimotivasi oleh keinginan mereka untuk memperluas jaringan sosial, kebutuhan pencarian ketenaran, ekspresi diri, dan penciptaan identitas.

Hasil penelitian menunjukkan bahwa teori Uses and Gratification dapat digunakan untuk menjelaskan motivasi yang mendasari narasumber penelitian dalam berpartisipasi pada \#tantangan di TikTok. Penelitian ini menggambarkan hubungan antara Uses and Gratification Theory dan data empiris. Hasilnya membuktikan bahwa faktorfaktor narasumber untuk berpartisipasi dalam \#tantangan pada TikTok ternyata saling berkaitan, dan peneliti menyimpulkan bahwa hiburan menjadi motivasi yang utama.

Kebosanan dan ketidakpuasan dalam kehidupan nyata mendorong Narasumber Penelitian untuk menggunakan aplikasi TikTok dengan tujuan meningkatkan suasana hati secara instan, beberapa pengguna mulai mengekspresikan diri dalam produksi video. TikTok merangsang kreativitas Narasumber Penelitian dengan mendorong pembuat konten untuk mengubah dan melebih-lebihkan kehidupan nyata mereka dengan cara yang dramatis dan lucu lewat fitur dan filter; Selain itu, peneliti juga menemukan bahwa pengguna mudah lupa waktu ketika menggunakan aplikasi TikTok. Pada penelitian ini, penulis juga menemukan bahwa micro-celebrities atau influencer memiliki tingkat kekuatan pengaruh tertentu pada pengguna Tiktok, karena mereka mampu mengatur tren di platform tersebut, tetapi pengguna tiktok tetap waspada terhadap aktivitasaktivitas komersil yang dilakukan oleh para influencer.

Pada artikel ini penulis memiliki tujuan untuk menemukan kesamaan antar jurnal terdahulu mengenai eksplorasi pengguna tiktok dan kebutuhan sosial ditinjau dari Uses and Gratification Theory. Konsep yang menjelaskan tentang motivasi atau ekspektasi dari penggunaan media kerap kali dibahas pada Gratifikasi yang diharapkan (Gratification Sought). Pada penelitian ini, maka Gratifikasi yang diharapkan (Gratification Sought) merupakan sebuah bentuk motivasi atau ekspektasi yang dirasakan oleh pengguna sebelum menggunakan aplikasi TikTok. Sedangkan Gratifikasi yang didapatkan (Gratification Obtained) adalah kepuasan nyata yang diperoleh pengguna setelah menggunakan media tertentu (Rosengren, 1985: 27)

Pada teori uses and gratification, pengguna media dianggap secara aktif memilih media yang dapat memenuhi kebutuhan nya, dan meninggalkan media yang dianggap kurang berguna. Dalam memilih media massa, pengaruh utama adalah pada dasar kebutuhan nya. Pengguna tidak akan tertarik pada media massa lain jika memang dianggap tidak dapat memenuhi kebutuhan individu tersebut. Maka, dari hak tersebut timbul motif yang akan mengarahkan pada perilaku individu dalam menggunakan media (Selektivitas Individu). 
Selanjutnya, akan muncul pertanyaan apakah motif-motif yang ada dapat dipenuhi setelah individu tersebut menggunakan suatu media tertentu. Konsep mengukur kepuasan inilah yang kemudian disebut sebagai Gratification Sought (GS) dan Gratification Obtained (GO).

Pada tulisan Kriyantono tahun 1985 yang bertajuk "Teknik Riset Komunikasi" memaparkan bahwa Gratification Sought adalah sebuah motif yang kemudian dapat memotivasi seseorang untuk memilih suatu media tertentu, dan Gratification Obtained adalah kepuasan yang didapatkan seseorang selepas menggunakan suatu model media. Dari hasil GS dan GO kemudian dapat diketahui tingkat kepuasan audiens berdasarkan kesenjangan nya.

Penggunaan media internet yang telah dipaparkan pada penelitian-penelitian sebelumnya akan dibahas pada penulisan ini. Internet sebagai media baru (new media) memberikan pemenuhan kebutuhan pengguna baik dari sisi sosial (social need) maupun psikis (psychological need). Federman dalam Karman (2013) menyatakan ada 5 gratifikasi yang ditemukan, yaitu Pengidentitasan diri (Identity Signalling), Pengawasan (surveillance), Hubungan sosial (social relations), pelarian diri (escapism) dan yang terakhir adalah hiburan (entertainment). Berdasarkan konsep diatas peneliti akan melakukan penelitian lanjutan untuk mengetahui eksplorasi konsep diri pada pengguna TikTok.

\section{METODE}

Metode penelitian adalah alat untuk memudahkan penelitian dalam memperoleh jawaban dari permasalahan dalam penelitian. Metode yang digunakan harus tepat agar hasil yang diperoleh sesuai, yaitu dapat mencerminkan relevansi antara metode dengan masalah yang diangkat dalam analisa.

Peneliti memakai pendekatan kualitatif pada analisis penelitian ini. Penelitian kualitatif adalah penelitian yang dimanfaatkan untuk meneliti kondisi objek nyata alamiah dimana posisi peneliti sebagai instrumen kunci mengumpulkan data secara triangulasi (gabungan) dan analisis data nya bersifat induktif. Hasil penelitian kualitatif akan lebih menekankan pada makna generalisasi (Sugiyono, 2014).

Rakhmat (2003) juga menjelaskan bahwa penelitian kualitatif akan menelaah secara matang pada kehidupan sehari-hari, bersifat holistik, berakhir pada sebuah verstehen (pemahaman), mengungkapkan sebuah tema dan pernyataan asli dan menerangkan perspektif orang dalam setting tertentu, Penelitian kualitatif juga akan menghasilkan berbagai penerjemahan dengan instrumentasi yang tidak baku serta menganalisisnya dalam bentuk kalimat.

Metode penelitian yang dipilih oleh peneliti adalah metode penelitian studi kasus. Dimana, studi kasus menurut Creswell adalah penelitian yang digunakan terhadap suatu objek yang disebut kasus, kemudian dilakukan secara menyeluruh dan mendalam dengan menggunakan berbagai macam sumber informasi (dalam Gunawan, 2014:114).

Pendekatan studi kasus peneliti gunakan karena studi kasus berguna dalam memberikan jawaban atas pertanyaan utama "why". Peneliti mengembangkan pertanyaan penelitian dengan kalimat pertanyaan "how" atau "what". Hal tersebut sesuai dengan penelitian yang mengeksplorasi suatu kasus, sesuai dengan tujuan penelitian ini. 


\section{PEMBAHASAN}

Tabel 2

Analisa pada Asumsi - Asumsi Dasar Teori Uses and Gratification

\begin{tabular}{lccccc}
\hline Unit Analisis : & Dwi Putri & Dian Novita & Bucknell & Johannes Ahlse, & Yuxin Yang \\
Asumsi Dasar & Robiatul & Sari Chandra & Bossen, & Felix Nilsson, & (2020) \\
dari Uses and & Adawiyah & Kusuma, & Christina and & Nina Sandström & \\
Gratification & $(\mathbf{2 0 2 0 )}$ & Roswita & Kottasz, Rita & (2020) & \\
& & Oktavianti & $(\mathbf{2 0 2 0})$ & & \\
& & $(2020)$ & & & \\
& & & & &
\end{tabular}

\begin{tabular}{l}
\hline Khalayak \\
dianggap aktif \\
dan \\
penggunaan \\
media massa \\
diasumsikan \\
memiliki \\
tujuan
\end{tabular}

Dalam proses

komunikasi

massa, inisiatif

lebih banyak

berkaitan

dengan

pemuasan

kebutuhan dan

pemilihan

media terletak

pada anggota

khalayak

Setiap pengguna
dapat terlibat
secara aktif
maupun pasif
dalam memilih
media yang
bermanfaat bagi
dirinya

\section{Penggunaan \\ Alasan} media sosial TikTok terdapat motivasi yang mendasari seseorang untuk mencapai kebutuhannya, motivasi tersebut tumbuh karena secara sadar memahami manfaat dari penggunaan aplikasi TikTok

Penilaian tentang arti kultural dari media massa harus ditangguhkan sebelum diteliti lebih dahulu orientasi khalayak
Dalam pemanfaatan aplikasi TikTok narasumber banyak menggunakan aplikasi ini sebagai media komunikasi untuk mencari teman baru ataupun mempererat hubungan dengan teman dekat

Dijelaskan

bahwa laki - laki

di Denmark tidak memilih menggunakan TikTok narasumber menggunakan aplikasi TikTok inipun karena dorongan sosial yang berasal dari teman (audiens)

159 dari 300 narasumber mengetahui penggunaan dan gratifikasi yang didapatkan

Semua narasumber merasa terhibur dan puas setelah menggunakan aplikasi TikTok juga setelah mengunggah video ke TikTok dan mereka juga merasa kreatifitasnya semakin meningkat.

Semua narasumber menanggapi komentar buruk dengan
Dalam penelitian Dalam

dijelaskan bahwa penggunaan

penggua secara Tiktok Pengguna aktif memilih

tiktok dengan tujuan dalam pemuasan kebutuhannya memiliki tujuan untuk pemuasan

$\begin{array}{ll}\text { Narasumber } & \text { Terdapat } \\ \text { secara sadar } & \text { pemuasan } \\ \text { memahami } & \text { konten, } \\ \text { manfaat hiburan, } & \text { kreatvitas } \\ \text { sosialisasi, } & \text { produksi dan } \\ \text { pencarian } & \text { interaksi } \\ \text { informasi, } & \text { pengguna dalam } \\ \text { kenyaman, status } & \text { mencari, } \\ \text { dan identitas diri } & \text { menggunakan } \\ \text { pada aplikasi } & \text { dan membagikan } \\ \text { TikTok. Hal ini } & \text { informasi pada } \\ \text { dikatakan kuat } & \text { penggunaan } \\ \text { karena adanya } & \text { TikTok. }\end{array}$
\#challenge yang menjadi daya tarik penggunaan TikTok

Tidak dijelaskan Narasumber mengikuti tantangan atau challenge berdasarkan keikutsertaan beberapa artis yang mereka ikuti

\author{
Terdapat \\ pemuasan \\ produksi dan \\ interaksi \\ pengguna dalam \\ mencari, \\ dan membagikan \\ informasi pada \\ TikTok.
}

Narasumber melakukan Peer Interaction dan menjadi microinfluencer dalam aplikasi TikTok 
menjadikan

komentar

tersebut

pembelajaran

untuk

kedepannya

Tabel 3.

Analisa pada Gratification Sought dan Gratification Obtained

\begin{tabular}{c}
\hline Unit Analisis : \\
Gratification \\
Sought dan \\
Gratification \\
Obtained
\end{tabular}

$\begin{array}{cc}\text { Dwi Putri } & \text { Dian Novita } \\ \text { Robiatul } & \text { Sari Chandra } \\ \text { Adawiyah } & \text { Kusuma, } \\ (\mathbf{2 0 2 0}) & \text { Roswita } \\ & \text { Oktavianti }\end{array}$

(2020)

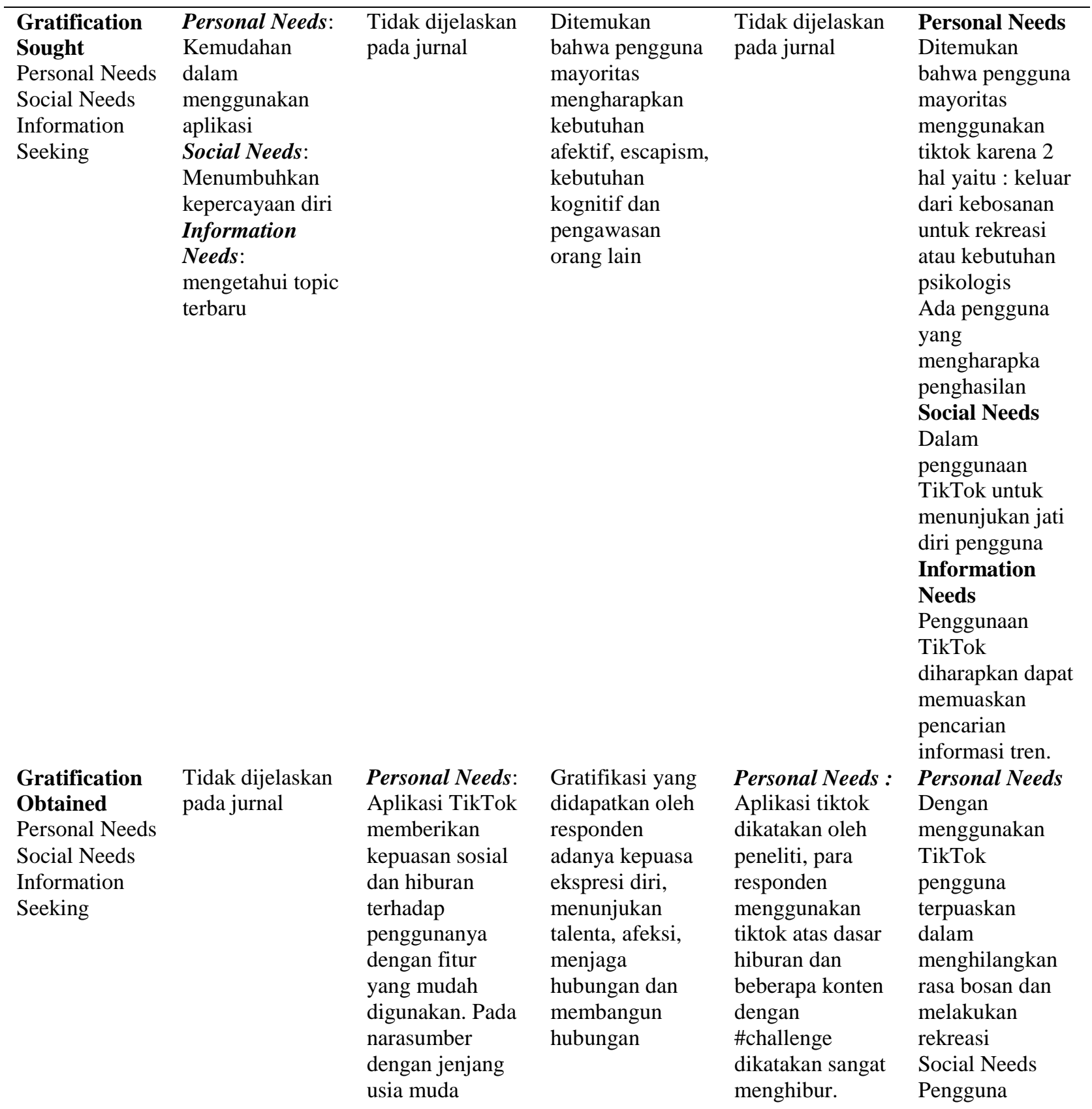


mereka

menggunakan

aplikasi TikTok

untuk mengikuti

perkembangan

sosial, sedangkan

narasumber

dengan jenjang

usia yang lebih

dewasa mereka

menggunakan

aplikasi TikTok

untuk mengisi

waktu luang

Social Needs:

Dapat

berinteraksi

dengan rekan

dan juga

menambah

teman melalui

aplikasi TikTok

Information

Needs: wawasan

kepada

penggunannya

dalam mengedit,

membuat konten,

mendapat ilmu

menari dan

memasak.
Social Needs :

Dikatakan

mayoritas dari

pengguna akan

mengikuti

\#Challenge

ketika temannya

sudah mengikut

\#Challenge

tersebut karena

lebih mudah

mengikuti jika

sudah ada teman

yang mengikuti

Information

Seeking:

Mayoritas

pengguna

menyatakan

bahwa mereka

telah

menggunakan

aplikasi untuk

mengetahui

informasi terbaru

dan tren.
TikTok. Ada

responden yang

menyatakan

bahwa

terpuaskan

dalam

penggunaanya

karena dapat

menghasilkan

uang dengan

membuat konten

Social Needs :

Dalam

penggunaanya

responden

menyatakan

bahwa mereka

dapat

berinteraksi

dengan

temannya dan

juga dapat

mengikuti idola

serta kalangan

artis.

Information

Needs

Ditemukan

pengguna

mendapatkan

sebuah informasi

bermanfaat

seperti resep

dalgona coffee.

Tabel 4

Analisa pada Konsep Diri

\begin{tabular}{ccc}
\hline Unit Analisis : & Dwi Putri & Dian Novita \\
Konsep Diri & Robiatul & Sari Chandra \\
& Adawiyah & Kusuma, \\
& $(2020)$ & Roswita \\
& & Oktavianti
\end{tabular}

(2020)

\begin{tabular}{|c|c|c|c|}
\hline Faktor & Aspek Fisik & Aspek Fisik & Aspek Fisik \\
\hline \multirow{3}{*}{$\frac{\overline{\text { Internal }}}{\text { Aspek Fisik }}$} & Tidak dijelaskan & Ditemukan 2 & Tidak ditemukan \\
\hline & & narasumber yang & \\
\hline & Aspek Psikologis & merupakan siswa & Aspek Psikologis \\
\hline \multirow{11}{*}{$\begin{array}{l}\text { Aspek } \\
\quad \text { Psikologis }\end{array}$} & Ditemukan & SMP dan SMA & Ditemukan \\
\hline & peningkatan & menilai dirinya & bahwa konsep \\
\hline & kepercayaan diri & secara positif dan & diri dari \\
\hline & setelah & dirinya menarik. & sosial media \\
\hline & menggunkan & Sedangkan & TikTok \\
\hline & TikTok & narasumber & ditujukan untuk \\
\hline & & $\begin{array}{l}\text { lainnya } \\
\text { menganggap }\end{array}$ & $\begin{array}{l}\text { pencarian } \\
\text { ketenaran }\end{array}$ \\
\hline & & dirinya biasa saja & \\
\hline & & karena tidak suka & \\
\hline & & melebih-lebihkan & \\
\hline & & diri dan & \\
\hline
\end{tabular}

Aspek Fisik
Ditemukan
bahwa pengguna
merasa bias
mengikuti
\#challenge suatu
tarian karena
kelenturan
tubuhnya.
Aspek Psikologis
Ada yang
narasumber yang
merasa tidak
percaya diri
dalam kompetisi
yang dilakukan

Aspek

Tidak

dijelaskan

Aspek

Psikologis

Dikatakan bahwa

dalam aspek

konsep diri

sejumlah

responden merasa dapat

mengekspresikan

dirinya pada

aplikasi TikTok 


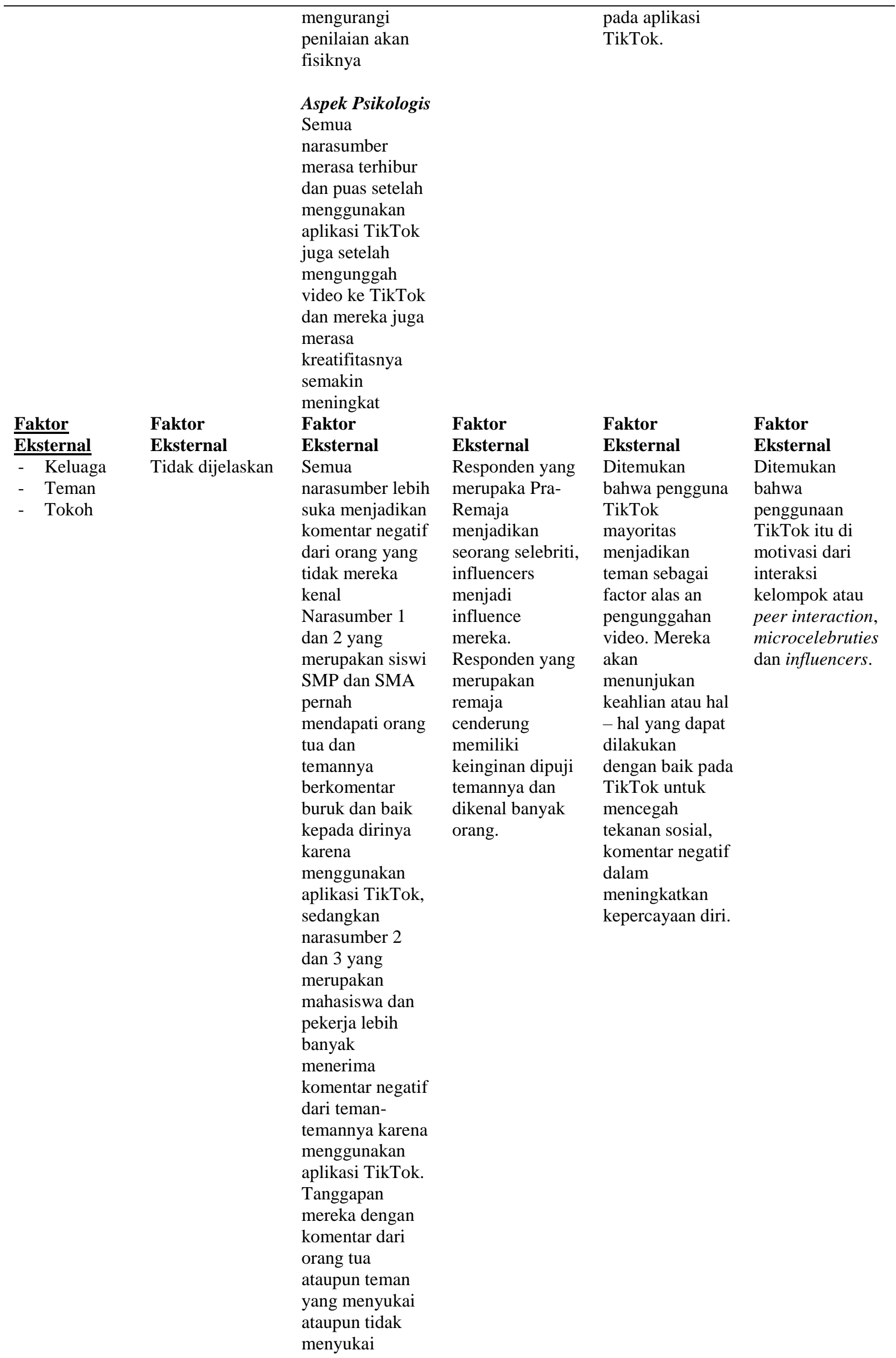




\author{
mereka \\ menggunakan \\ aplikasi TikTok \\ adalah menerima \\ apabila komentar \\ yang diberikan \\ masih bisa \\ diterima dan \\ tidak peduli \\ apabila komentar \\ yang diberikan \\ terlalu berlebihan
}

Pada jurnal pertama yang berjudul "Pengaruh Penggunaan Aplikasi TikTok Terhadap Kepercayaan Diri Remaja di Kabupaten Sampang" peneliti menemukan bahwa adanya pengaruh kuat antara penggunaan sosial media TikTok dengan kepercayaan diri remaja di Kabupaten Sampang. Nilai koefisien regresi bernilai (+) positif dimana penggunaan aplikasi TikTok memiliki dampak positif pada kepercayaan diri pengguna nya. Pada Teori Uses and Gratification yang dikemukakan oleh Maslow, Audiens dapat memilih media mana saja yang menjadi manfaat bagi dirinya, baik secara aktif maupun pasif. Hal ini tentu memperlihatkan bahwa adanya motivasi dalam diri seseorang ketika menggunakan aplikasi TikTok sebagai media, bahwa mereka mengakui aplikasi TikTok dapat memenuhi kebutuhan yang ada dalam dirinya. Secara sadar pengguna mengerti dan memahami dengan baik dampak penggunaan aplikasi TikTok, salah satu dampaknya dapat mereka rasakan pada tingkat kepercayaan diri masing-masing pengguna.

Jurnal kedua yang berjudul "Penggunaan Aplikasi Media Sosial Berbasis Audio Visual dalam Membentuk Konsep Diri (Studi Kasus Aplikasi Tiktok)" ditemukan bahwa tingkat kepercayaan diri seseorang dapat dipengaruhi oleh kegiatan komentar pada aplikasi TikTok. Melalui komentar-komentar yang positif dari para audiens dapat membangun kepercayaan diri pengguna, dan melalui komentar negatif pun para pengguna belajar untuk menyikapi dan mengintrospeksi diri. Pada penelitian ini ditemukan bahwa melalui aplikasi TikTok, kreatifitas dapat diasah melalui edit video, membuat video kreatif, mendapatkan ilmu dan info baru serta meningkatkan ketrampilan seperti memasak. Narasumber-narasumber pada penelitian ini menyebutkan bahwa tidak ada faktor fisik dalam mengunggah dan menggunakan aplikasi TikTok, tetapi lebih condong ke faktor psikis dimana ada rasa puas dan merasa terhibur ketika menggunakan aplikasi TikTok. Para pengguna aplikasi TikTok ini juga mendapatkan penilaian diri melalui komentar-komentar yang diberikan oleh teman maupun pengguna TikTok lain yang tidak dikenal.

Kemudian pada jurnal yang ditulis oleh Bucknell Bossen, Christina and Kottasz dan Rita pada tahun 2020 berjudul "Penggunaan dan Pemenuhan Kepuasan yang Dicari oleh Pengguna TikTok Pra-remaja dan Remaja”, Peneliti menemukan bahwa Perilaku konsumtif pasif, partisipatif dan kontributif menjadi salah satu dampak pengaruh dari efek hiburan dalam aplikasi TikTok. Perilaku konsumtif tersebut dimotivasi oleh keinginan para pengguna untuk memperluas jaringan sosial mereka, pemenuhan kebutuhan akan ketenaran, ekspresi diri dan juga penciptaan identitas. Para remaja menggunakan aplikasi TikTok untuk membantu memperluas jaringan sosial mereka (Shao, 2009), membenarkan pernyataan Tanta (2014) dan 
Urista (2018) bahwa audiens pra-remaja tertarik pada hal tersebut, karena mereka baru mulai memahami diri mereka sendiri sebagai individu sosial dan juga baru mulai membentuk identitas mereka. Pada penelitian ini ditemukan juga bahwa pra-remaja mencari teman dan jaringan baru di TikTok dengan cara yang sama seperti para remaja. Fakta lain yang didapat dari penelitian ini bahwasanya kelompok pengguna sangat muda seperti pra-remaja dan remaja yang dapat mengakses aplikasi TikTok dapat mengakibatkan mereka untuk tumbuh lebih cepat karena mereka dapat dengan mudah meniru konten yang dibuat oleh pengguna yang lebih dewasa. Hal ini tentu kan merubah identitas dan cara pandang mereka akan sesuatu. Konsep diri tentu sangat berkaitan erat dengan penggunaan aplikasi TikTok di usia muda seperti mereka. Para pengguna aplikasi TikTok setuju bahwa mereka menggunakan aplikasi TikTok untuk memenuhi kebutuhan akan pujian dan pengakuan sosial serta penciptaan identitas diri dan pemenuhan keinginan dalam mencari ketenaran, ditambah juga dengan pemeliharaan dan pembangunan hubungan. Salah satu temuan baru dan penting dari penelitian ini adalah bahwa individu pengguna aplikasi TikTok memang membuat video untuk mendapatkan reaksi, pujian dan pengakuan dari pengguna lain nya.

Sama hal nya dengan jurnal yang dikemukakan oleh Johannes Ahlse, Felix Nilsson, Nina Sandström tahun 2020 berjudul "Inilah Saatnya TikTok: Mengeksplor Motivasi Generasi-Z yang Ikut Berpartisipasi pada \#Tantangan", Peneliti menemukan bahwa Teori Uses and Gratification dapat digunakan untuk menjelaskan motivasi yang mendasari narasumber penelitian ketika berpartisipasi pada \#tantangan di TikTok. Penelitian ini menggambar hubungan jelas antara Teori uses and gratification dengan data empiris penelitian. Peneliti mengusulkan 6 motivasi pengguna TikTok dalam pembuatan konten video \#tantangan yaitu sebagai sarana hiburan, wadah untuk sosialisasi, pembentukan Identitas Pribadi, sebagai pencarian informasi, bentuk kenyamanan, dan juga sebagai Status diri. Dari semua faktor ini, hiburan dianggap sebagai faktor pendorong utama, seperti yang disarankan oleh penelitian sebelumnya (Berthon et al., 2008; Muntinga et al., 2011).

Terakhir, jurnal yang berjudul "Memahami Penggunaaan TikTok pada kelompok Dewasa Muda (Young Adults) : Video Nyata, Video Kreatif yang Membuat Hari Anda Lebih Menyenangkan" oleh Yuxin Yang (2020). Peneliti menemukan bahwa kebosanan dan ketidakpuasan dalam kehidupan nyata menjadi alasan utama para narasumber penelitian pengguna aplikasi TikTok membuat video TikTok untuk meningkatkan suasana hati mereka secara instan dan juga sebagai bentuk ekspresi diri mereka. TikTok mengasah kreativitas pengguna dengan menginspirasi mereka untuk mengubah dan melebih-lebihkan kehidupan nyata dengan cara yang lebih dramatis dan lucu melalui efek dan filter video yang tersedia. Dengan berkreasi dalam video TikTok yang lucu dan kreatif ini, pengguna dapat mengurangi tingkat stres yang mereka alami, serta menjadi bentuk ekspresi diri mereka yang tersembunyi dan kemudian membantu untuk menonjolkan sisi-sisi positif dalam kehidupan mereka. Munculnya TikTok memungkinkan mereka untuk melepas diri yang telah mereka sembunyikan dalam kehidupan nyata, dan video TikTok yang berdurasi pendek membuat produksi video lebih mudah dan cepat. TikTok memberi mereka tempat yang aman untuk mengembangkan khas atau ciri diri mereka dengan memproduksi video pendek yang kreatif dan lucu. 


\section{KESIMPULAN}

Teori uses and gratification memaparkan bahwa pengguna berhak menentukan media apa yang cocok untuk kebutuhan dan kepuasan mereka. Kepuasan yang dicari oleh tiap individu akan berbeda-beda sesuai dengan konsep diri yang ingin dibentuk. William D Brooks menyatakan bahwa konsep diri merupakan pengetahuan dan penilaian mengenai diri kita. Pandangan tentang diri ini dapat bersifat psikologis, sosial dan fisik (dalam Widiarti, 2017:137).

Jika melihat seluruh penelitian dan jurnal yang dibahas pada bagian pembahasan, dapat disimpulkan bahwa eratnya dampak pembentukan konsep diri dalam penggunaan aplikasi TikTok. Aplikasi ini mempermudah para pengguna nya untuk mendapatkan kepercayaan diri melalui komentar, konten, serta hiburan dalam aplikasi. Selain hiburan, aplikasi ini juga membentuk konsep diri seseorang dengan memberikan wawasan tentang berbagai hal, mulai dari memasak, menari, bernyanyi, ketrampilan umum, dan masih banyak informasi lain nya. Gratification Obtained (GO) adalah suatu pemenuhan kebutuhan yang dicari untuk mendapatkan kepuasan saat menggunakan media massa, Aplikasi TikTok efektif memberikan rasa puas di hati para narasumber penelitian pengguna TikTok, yang bermula dari keinginan mereka untuk mengisi waktu luang dengan hiburan dan juga kebutuhan sosial.

Narasumber penelitian juga memaparkan bahwa ada dorongan sosial dari lingkungan mereka untuk menggunakan aplikasi ini, karena aplikasi TikTok dianggap efektif sebagai media komunikasi pencari teman baru atau sekedar mempererat hubungan teman dekat. Para narasumber merasa puas dan senang karena kebutuhan mereka terpenuhi ketika menggunakan aplikasi TikTok. Aplikasi TikTok juga dianggap sebagai sebuah "pelarian" dari kenyataan atau realita kehidupan tidak menyenangkan yang dialami oleh para pengguna. Dengan menggunakan aplikasi ini, Pengguna merasa bebas berekspresi, dapat menunjukan sisi diri nya yang terkubur dalam pribadi sehari-hari mereka.

\section{DAFTAR PUSTAKA}

Adawiyah, Dwi Putri Robiatul. 2020. "Pengaruh Penggunaan Aplikasi TikTok Terhadap Kepercayaan Diri Remaja Di Kabupaten Sampang.” Jurnal Komunikasi 14 (2): 135-48.

Ahlse, Johannes, Felix Nilsson, and Nina Sandström. 2020. "It's Time to TikTok: Exploring Generation Z's Motivations to Participate in \#Challenges.” Jonkoping University.

Azeharie, Suzy. 2014. “Analisis Penggunaan Twitter Sebagai Media Komunikasi Selebritis Di Jakarta.” Jurnal Komunikasi 6 (2): 83-98.

Berthon, P, L Pitt, M Parent, and J Berthon. 2009. "Aesthetic and Ephemerality; Observing and Preserving the Luxury Brand.” California Management Review 52 (1): 45-66.

Brooks, William D., and Philip Emert. 1976. Konsep Diri Manusia. Jakarta: EGC.

Bucnknell, Christina Bossen, and Rita Kottasz. 2020. "Uses and Gratifications Sought by PreAdolescent and Adolescent TikTok Consumers." Young Consumers 21 (4): 463-78.

Creswell, J.W. 2010. Research Design: Pendekatan Kualitatif, Kuantitatif, Dan Mixed. Yogyakarta: PT Pustaka Pelajar. 
Dariyo, Agoes. 2011. Psikologi Perkembangan Anak Tiga Tahun Pertama. Bandung: PT. Refika Aditama.

Federman. 1998. "Gratification and Seeding Behavior of Online Adolescent." National Televition Violence 3.

Kriyantono, Rachmat. 2014. Teknik Praktis Riset Komunikasi. Jakarta: Prenada Media Group.

Kusuma, Dian Novita Sari Chandra, and Roswita Oktavianti. 2020. "Penggunaan Aplikasi Media Sosial Berbasis Audio Visual Dalam Membentuk Konsep Diri (Studi Kasus Aplikasi Tiktok)." Koneksi 4 (2): 371-79.

Palmgreen, Philip, Lawrence Wenner, and Karl Rosengren. 1985. "Uses and Gratifications Research: The Past Ten Years.” Media Gratifications Research, 11-37.

Rakhmat, Jalaludin. 2012. Metode Penelitian Komunikasi. Bandung: PT. Remaja Rosdakarya.

Romli, Khomsahrial. 2016. Komunikasi Massa. Jakarta: PT. Grasindo.

Shao, JinHua, and SangKhee Lee. 2020. "The Effect of Chinese Adolescents' Motivation to Use Tiktok on Satisfaction and Continuous Use Intention." The Journal of Convergence on Culture Technology 6 (2): 107-15.

Sugiyono. 2014. Metode Penelitian Pendidikan Pendekatan Kuantitatif, Kualitatif, Dan R\&D. Bandung: Alfabeta.

Yang, Yuxin, and Elana Zilberg. 2020. "Understanding Young Adults' TikTok Usage." University of California. 